\title{
The absence of strategy in orepass planning, design and management
}

\author{
J. Hadjigeorgiou Lassonde Institute for Mining, University of Toronto, Canada
}

T.R. Stacey School of Mining Engineering, University of the Witwatersrand, South Africa

\section{Abstract}

Material transfer in underground mines often relies on ore and waste pass systems. Over the years the authors have investigated the design and performance of orepass systems in several Canadian and South African mines. It has been recognised that while most mining operations have either implicitly or explicitly clearly defined objectives aimed to design and successfully operate orepass systems, there seems to be an absence of a strategy on how to best attain these goals. Consequently, it is not surprising that the majority of operations reviewed by the authors experience a number of problems of varying degrees of severity and economic consequences. This is illustrated by reference to both South African and Canadian operations. The second part of this paper focuses on a review of tactical interventions to rectify orepass problems or mitigate their impact. The paper closes with a framework for a flexible strategy for the design and operation of orepass systems.

\section{$1 \quad$ Introduction}

Most underground operations have relatively well defined strategies from the feasibility to the design stage. These include strategies for data collection, construction of geological and geomechanical models for the design and support of underground excavations. It is recognised, however, that the same level of attention is not given to vertical or near vertical excavations, such as orepasses, as for horizontal excavations.

This paper draws from the experience of the authors in several mines and reaches the disappointing conclusion that there is an absence of strategy in orepass planning, design and management. Consequently, it is not surprising that a large number of operations experience a number of problems, of varying degrees of severity and economic consequences.

The case of orepass systems is somewhat complex as the major design decisions are often made at the early stages of design when there are often insufficient data. Further complications, specific to orepasses, lie in that it is not only necessary to maintain the stability of the excavation but also to ensure the noninterrupted material transfer from one level to another.

\section{Orepass system failures}

System failure can be the result of any component failure. An orepass system is considered to have failed if it does not meet its required task of non-interrupted material flow for any given time. Orepass failures include structural failures along the wall as shown in Figure 1, stress related degradation resulting in orepass expansion (Figure 2), and erosion of the orepass such as in Figure 3. All these failures eventually lead to rehabilitation requirements. 

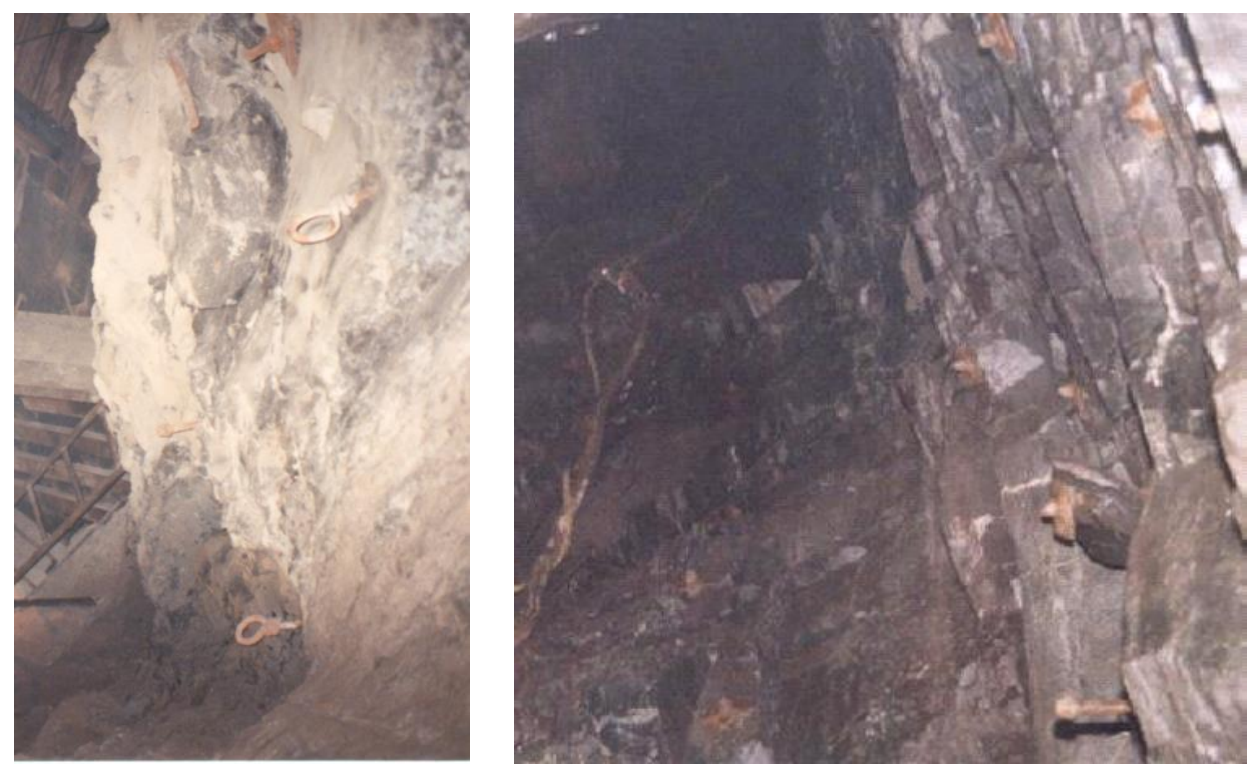

Figure 1 Structural failures in orepasses
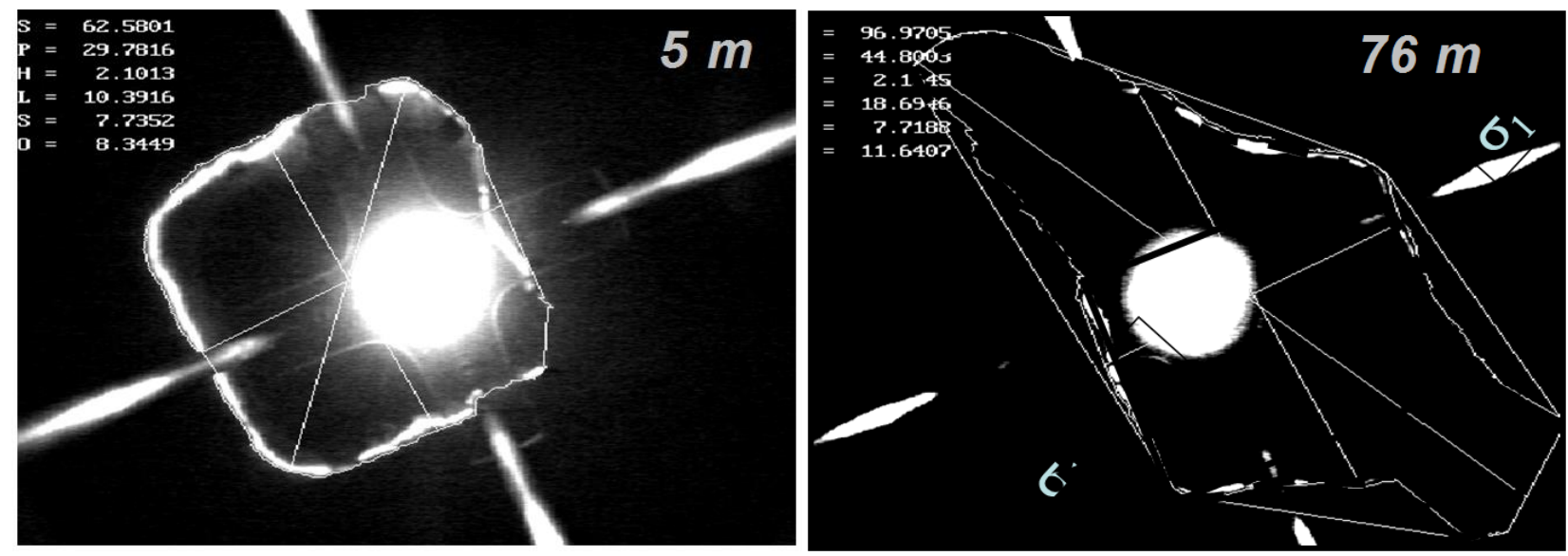

Figure 2 Stress related degradation after a couple of months of use $(20,000$ tonnes of waste), after Goulet (2000)

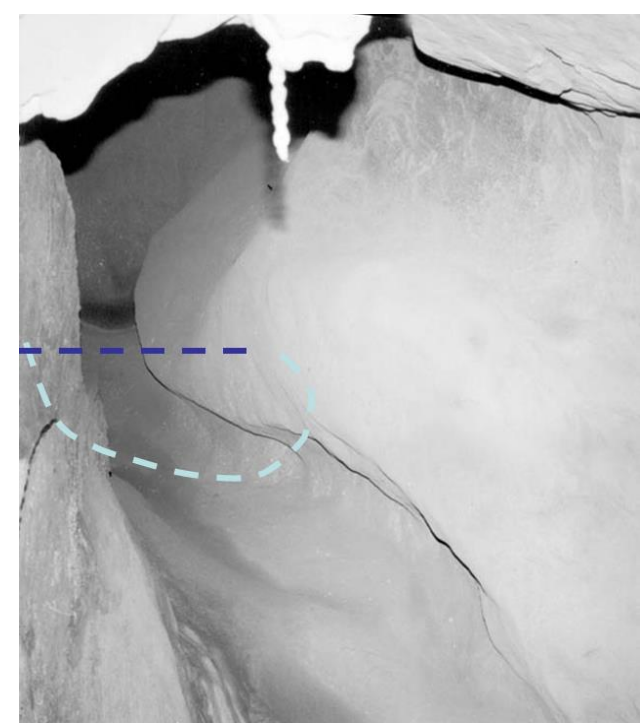

Figure 3 Rock pass wall wear condition after 6 years $(6,000,000$ tonnes of ore) 
The other types of observed orepass failures involve the interruption of material transfer. The transfer of coarse material can result in hang-ups due to interlocking arches, while the transfer of fine material results in hang-ups due to cohesive arches (Figure 4). If flow is not restored there can be significant consequences for a mine. Restoring flow involves the use of a variety of techniques that can cause further damage to the orepass and are subject to their own set of safety concerns.

Another concern in orepass systems is the development of mud rushes or sudden inflows of mud. Butcher et al. (2005) suggested that the process originates with "sticky" material formed from the fines and water adhering to the sides of an ore rock pass or chute and impeding material flow and ultimately resulting in blockage. Once a blockage or hang-up has occurred, further fines and water accumulating above the restriction provide the driving force for a mud rush when the chute is open or some disturbance of the blockage material occurs.

a)

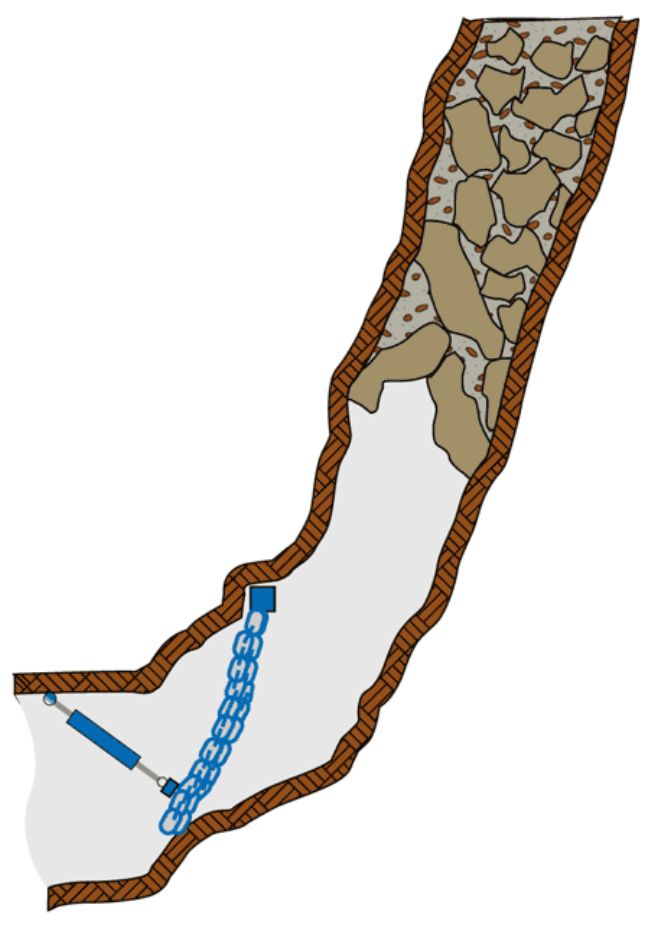

b)

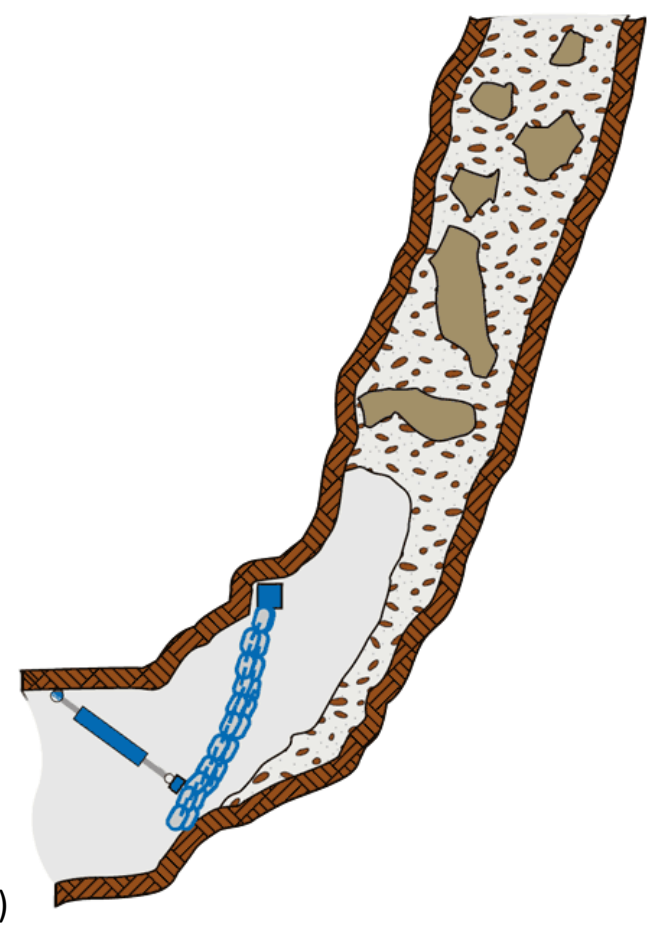

c)

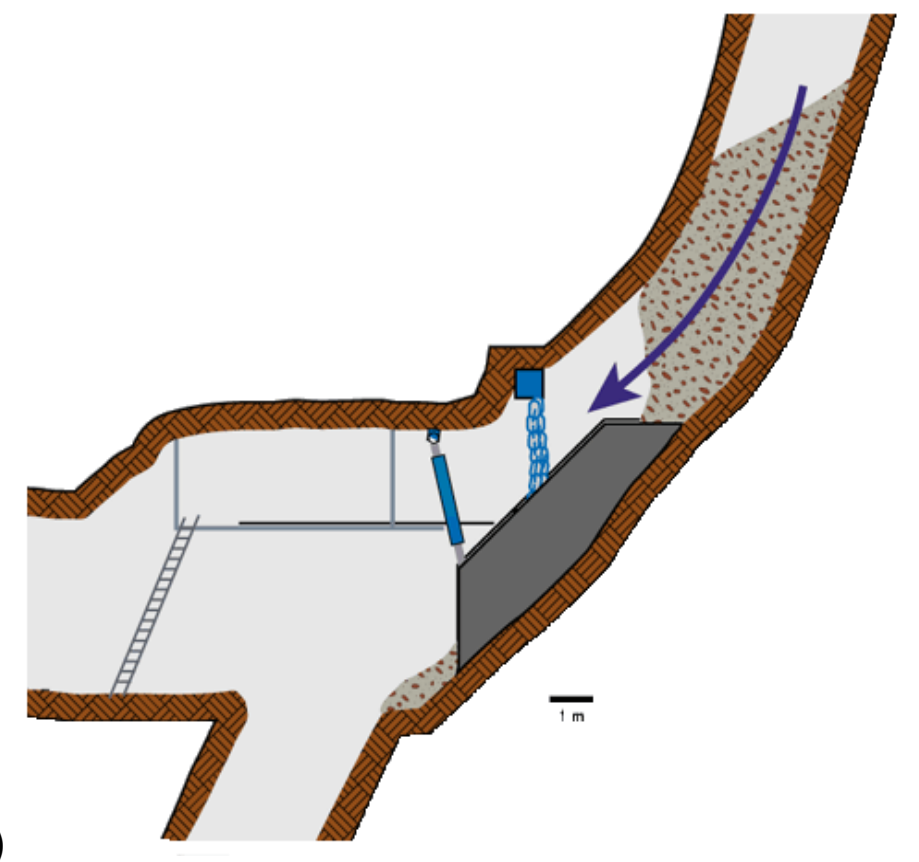

Figure 4 Hang-ups caused by: a) interlocking arches; b) cohesive arches and c) mud rushes 
A successful strategy implies that the objectives in the planning, design, and operation of orepass systems are met. The corollary is that if the strategies are not fully successful they would be revised. This, however, contradicts the actual situation where extensive reviews of both South African and North American mines report a series of documented failures.

In a study of more than 200 individual passes in South African deep level gold mines, i.e. more than $2,000 \mathrm{~m}$, it was observed that more than $50 \%$ of the passes had stability problems, and $16 \%$ had been abandoned (Joughin and Stacey, 2005a, 2005b). The severity of the pass problem at deeper levels was illustrated by the fact that the maximum span of about $60 \%$ of the passes had doubled, or more, in size and that more than $20 \%$ of the passes had been abandoned. In Canada, based on data from over 20 mines, some type of material flow problems were reported at every site (Hadjigeorgiou et al., 2005, 2008; Lessard and Hadjigeorgiou, 2006).

These failures transcend types of ore deposits, mining conditions and company culture. An explanation is required to understand the numerous problems associated with orepasses. One interpretation would be that orepass system design and operation cannot be improved. This would be fatalistic and erroneous. Another explanation would be that the pursued strategies fail for a variety of reasons. The authors have reached the rather disappointing conclusion that in several cases orepass failures are preceded by the absence of strategy from the feasibility stage to the design and operational stages.

\section{$3 \quad$ Tactical tools}

\section{1 Orepass management}

The management of an orepass is a complex procedure and is often complicated by production considerations. The two major parameters in the successful operation of orepasses are whether it is necessary to restore flow using blasting, and whether the mine implements a cushion policy. Frequent blasting to restore flow and break up hang-ups or blockages can damage the orepass or chute. Experience suggests that orepasses kept full mitigate the damage associated with material hitting the walls. A further advantage of this practice is that it provides confinement to the sides of the pass, thus reducing structural failure or scaling due to high stress, see Stacey and Swart (1997).

A successful orepass management strategy requires a clear management structure and discipline. It was further observed that at some sites, orepasses are operated under a flow-through regime, even though there are guidelines against it. The usual explanations for these deviations from the site guidelines was that hang-up incidences require operators to keep muck levels lower than expected, and the need to "keep feeding the mill". It is easier for the operation to be more disciplined in keeping waste passes full given the higher priority in hoisting ore.

\section{2 Material flow}

The proper dimensioning of orepass systems is primordial to ensure good material flow. An orepass should be dimensioned so as to avoid interlocking and cohesive hang-ups. Several guidelines are available to select these dimensions. The most reliable way to ensure that no oversize material enters an orepass is by use of appropriate block size infrastructure such as grizzlies, mantles and scalpers (Figure 5). Nevertheless, it has been difficult for some operations to invest in such infrastructure and at other places there is reluctance from workers to accept, arguing that they slow down production. 
a)

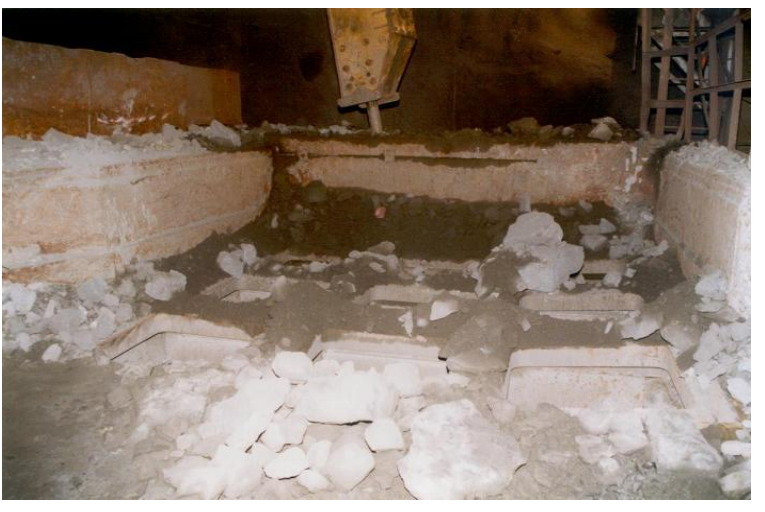

b)

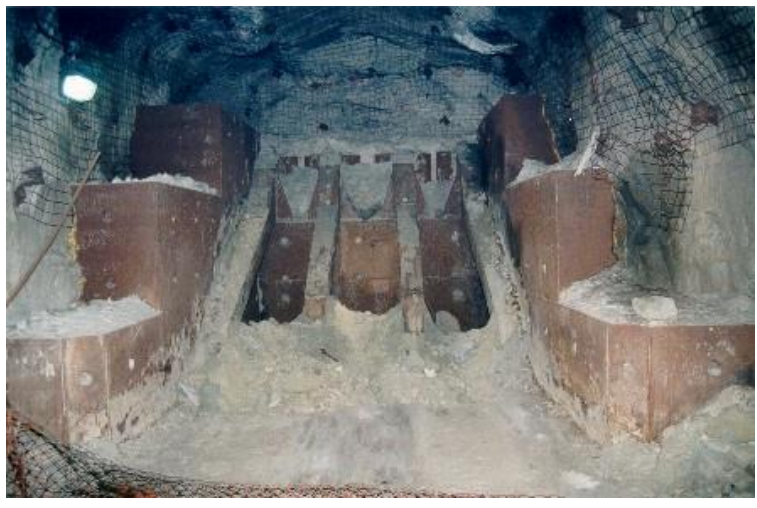

c)

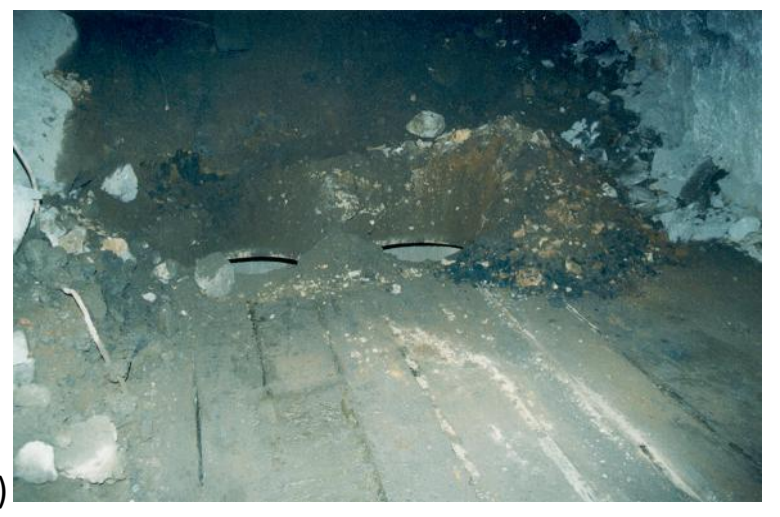

Figure 5 Block size control infrastructure: a) grizzly, b) scalper and c) mantle

\section{3 Performance and monitoring}

In comprehensive studies in South African and Canadian mines the authors recorded the lack of measurement, observation recording and documentation of data on orepass system in mines. This is more surprising given that there are a variety of monitoring systems accessible (Table 1). Given that orepass systems are critical elements of the material handling system, the lack of quality quantitative data has hindered the development of robust predictors of orepass performance.

Table 1 Muck level monitoring systems in Canadian orepasses, after Hadjigeorgiou et al. (2005)

\begin{tabular}{|c|c|c|}
\hline Type & & Comments \\
\hline \multirow[t]{3}{*}{ Direct } & Visual & $\begin{array}{l}\text { Evaluation of the muck level is performed periodically by } \\
\text { supervising personnel. Inaccurate. Cannot be automated }\end{array}$ \\
\hline & Measuring tape & $\begin{array}{l}\text { A weighted tape is used by supervising personnel to periodically } \\
\text { record the muck level. Cannot be automated }\end{array}$ \\
\hline & Laser & $\begin{array}{l}\text { Laser systems can provide real time muck level readings. Very } \\
\text { accurate. Can be automated. High capital cost. Sensitive to dust }\end{array}$ \\
\hline Indirect & Tonnage reconciliation & $\begin{array}{l}\text { Subtracting pass capacity and pass output to pass input (scoop } \\
\text { buckets). Highly inaccurate }\end{array}$ \\
\hline
\end{tabular}

\section{4 Liners}

Liners have been proven as a useful tool to maintain the performance of ore and waste pass systems as well as improving their longevity. Stacey and Swart (1997) suggest that the use of liners should be considered in weak rock or in fissile, scaling or closely jointed blocky rock as a way to prevent uncontrolled growth of the pass dimensions. Liners are a plausible defence mechanism to protect the sides of the excavation from impact load. A liner system should provide impact resistance superior to the rock mass. In 
most cases, liners are installed as a preventive measure before commissioning the orepasses, but also as repair work to prolong the useful life of the orepass. Figure $6 a$ is an example of a successful use of abrasion resistant shotcrete as a liner, while Figure $6 \mathrm{~b}$ is a liner application that failed due to poor quality control.

а)

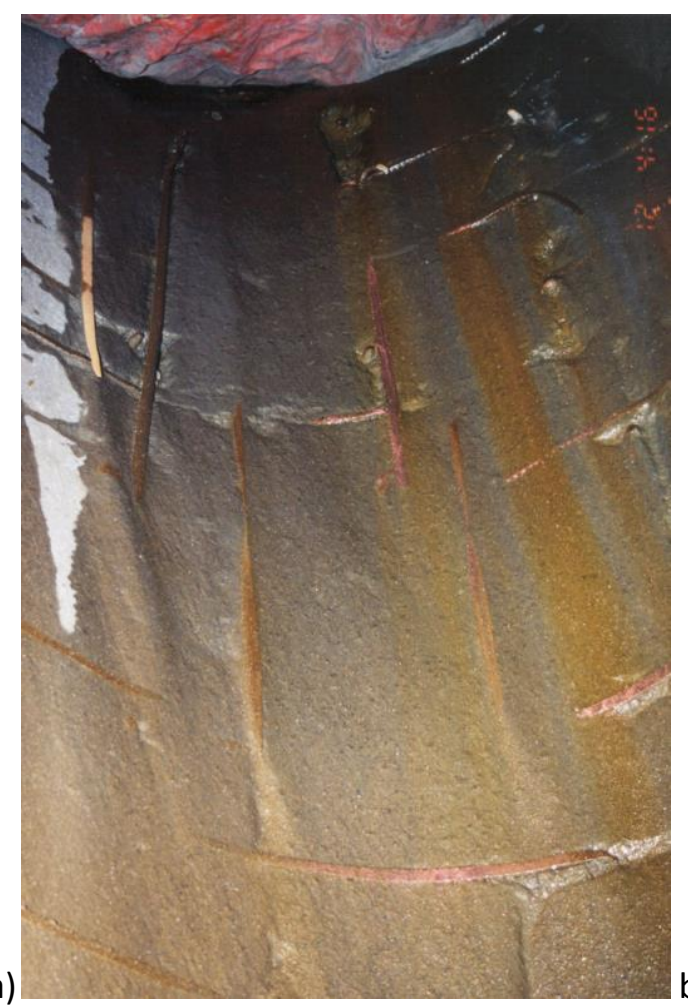

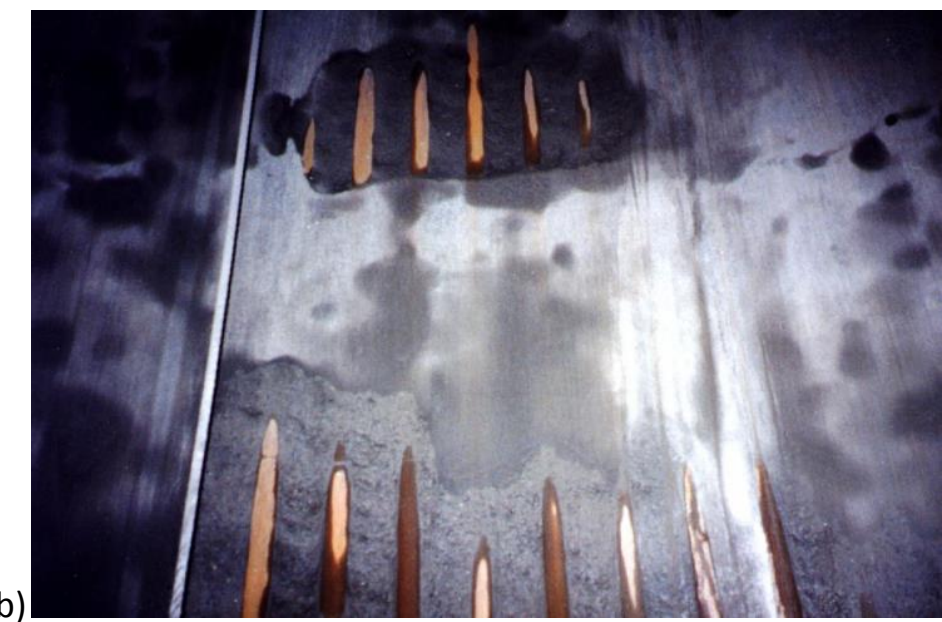

Figure 6 a) Successful application of abrasion resistant shotcrete liner in a vertical (storage) silo; photo after seven years in operation (10,000,000 tonnes) and b) poor quality control during application whereby shotcrete was not allowed to cure, resulted in excessive wear of shotcrete and rails

\section{$4 \quad$ Tactical interventions}

\section{1 Restoring flow}

The transfer of coarse material can result in hang-ups due to interlocking arches, while the transfer of fine material results in hang-ups due to cohesive arches. Blockages are localised in the vicinity of the chute while hang-ups are found in the orepass. If flow is not restored there can be significant consequences for the operation.

Table 2 lists the various methods employed to restore flow, with varying rates of success in Canadian mines. Figure 7 provides a matrix that can be used to identify the most appropriate technique to apply in order to restore flow in an orepass system. The first consideration depends on the type of a hang-up or blockage such as cohesive, interlocking or large single boulders that is observed. The next criterion is the location of the hang-up, i.e. whether it is at the chute or higher up in the orepass. Recommendations are then based on whether a particular strategy is pertinent or whether it can be used, but with a certain degree of caution. Several methods are simply not recommended. 
Table 2 Methods employed in Canadian mines to restore flow in orepasses

\begin{tabular}{ll}
\hline Category & Methods to Restore Flow \\
\hline Methods that employ water & $\begin{array}{l}\text { Introduction of water from above the hang-up or blockages } \\
\text { Introduction of water from a point below the blockage }\end{array}$ \\
Explosive-based methods & $\begin{array}{l}\text { Close range drilling and use of explosives } \\
\text { Drilling from a distance and use of explosives } \\
\text { Use of 'Sputnik' } \\
\text { Use of blasting poles }\end{array}$ \\
Mechanical methods & $\begin{array}{l}\text { Use of rock breakers to break down large boulders wedged at the tipping } \\
\text { point }\end{array}$ \\
\hline
\end{tabular}

\begin{tabular}{|c|c|c|c|c|c|c|c|c|}
\hline \multirow{4}{*}{$\begin{array}{l}\text { Release } \\
\text { Method }\end{array}$} & \multicolumn{8}{|c|}{ Type of Hang-up/blockage } \\
\hline & \multicolumn{3}{|c|}{ Cohesive Arches } & \multicolumn{3}{|c|}{ Interlocking Arches } & \multicolumn{2}{|c|}{ Single boulder } \\
\hline & \multicolumn{3}{|c|}{ Location } & \multicolumn{3}{|c|}{ Location } & \multicolumn{2}{|c|}{ Location } \\
\hline & Chute & $<20 \mathrm{~m}$ & $>20 \mathrm{~m}$ & Chute & $<20 \mathrm{~m}$ & $>20 \mathrm{~m}$ & Chute & $\begin{array}{c}\text { Tipping } \\
\text { point }\end{array}$ \\
\hline $\begin{array}{l}\text { Introduction of } \\
\text { water from } \\
\text { above }\end{array}$ & & & & & & & & \\
\hline $\begin{array}{l}\text { Introduction of } \\
\text { water from } \\
\text { below }\end{array}$ & & & & & & & & \\
\hline $\begin{array}{l}\text { Direct drilling } \\
\text { and explosives }\end{array}$ & & & & & & & & \\
\hline Use of Sputnik & & & & & & & & \\
\hline $\begin{array}{l}\text { Use of blasting } \\
\text { rods and } \\
\text { explosive }\end{array}$ & & & & & & & & \\
\hline $\begin{array}{l}\text { Use of long hole } \\
\text { drilling and } \\
\text { explosives }\end{array}$ & & & & & & & & \\
\hline
\end{tabular}

Legend:

Pertinent

Use with caution

Not applicable

Figure 7 Applicability matrix for selecting tactics to restore flow, after Hadjigeorgiou and Lessard (2010)

\section{2 Rehabilitation}

Rehabilitation of orepass systems is very costly and usually involves supporting an orepass under what can be extremely challenging and often dangerous conditions. Rehabilitation efforts can be undertaken either from outside or from inside with the advantages and limitations of each approach summarised in Table 3. 
Table 3 Advantages and Iimitations of rehabilitation techniques, after Mercier-Langevin and Hadj igeorgiou (2004)

\begin{tabular}{lll}
\hline Rehabilitation Techniques & From Inside & From Outside \\
\hline Advantages & $\begin{array}{l}\text { Any type of support can be installed } \\
\text { Any type of liner can be installed } \\
\text { Good understanding of the failure } \\
\text { mechanism }\end{array}$ & $\begin{array}{l}\text { Production can carry on as usual } \\
\text { Safe for personnel }\end{array}$ \\
& $\begin{array}{l}\text { The pass has to be emptied and } \\
\text { production stopped } \\
\text { Limitations }\end{array}$ & Onsafe for personnel cable bolts can be installed \\
& & Liners cannot be installed \\
& & $\begin{array}{l}\text { Poor understanding of the initial } \\
\text { failure mechanism }\end{array}$ \\
\hline
\end{tabular}

As a general rule, rehabilitation from inside a pass is dangerous, as it exposes workers to hazardous conditions. Any type of rehabilitation is expensive, whether the costs are direct or indirect. Depending on the type of rehabilitation performed on the pass, production may have to be stopped. In the case of a major orepass, this can mean production stoppage for the entire mine. Figure 8 illustrates examples of the required effort of rehabilitation work in orepasses.
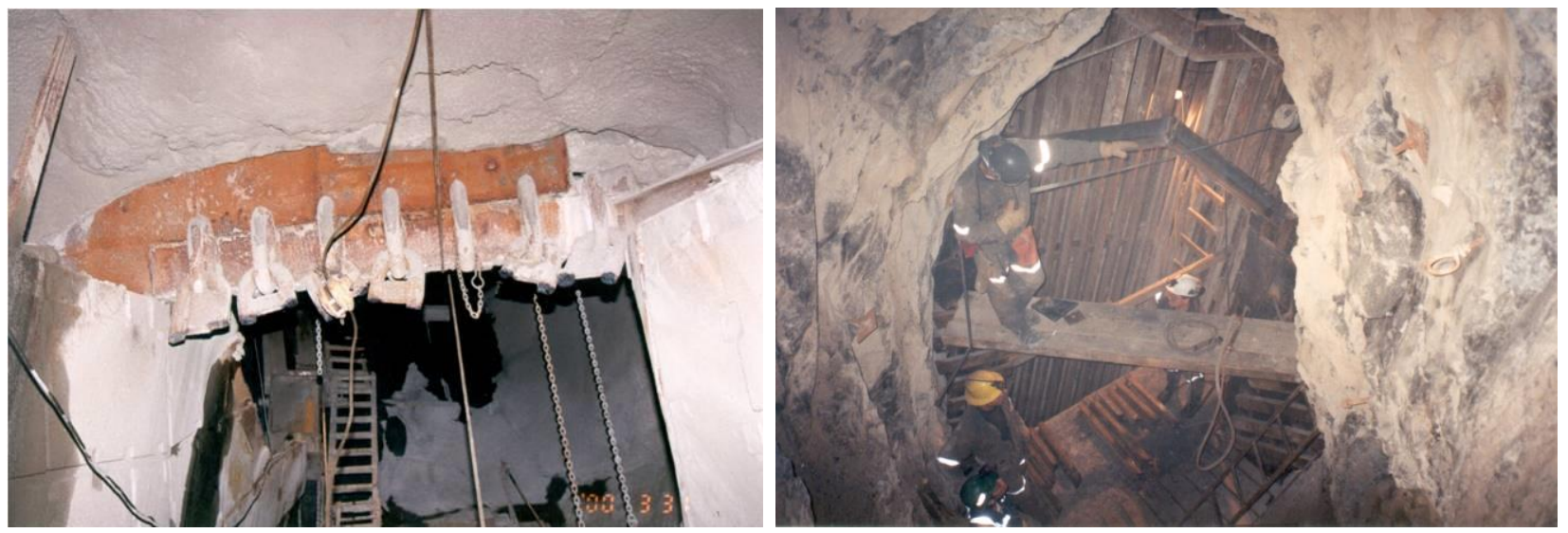

Figure 8 Examples of orepass rehabilitation work

The actual costs of rehabilitating passes are extremely high when compared with the initial cost of development. If one considers the stops in production during the rehabilitation then the costs can be staggering. This would imply that there is a need of a rehabilitation strategy at the early stages of design. Although it may be difficult to present at the feasibility stage there is a case to be made for planning rehabilitation, and there is a case for planning replacement passes to be developed simultaneously with the planned passes.

\section{$5 \quad$ Towards an orepass system strategy}

An orepass strategy would aim to ensure that an orepass system operates at its design performance throughout its design life. A well thought out strategy would employ a series of tactics or tools to ensure this objective. Arguably every mining company enjoys its own operating philosophy that invariably influences the design and operation of a mine. It would be a logical extension that this approach may be applied in the development of coherent strategies that would consider expectations from mine management, engineering, underground supervisory personnel, on the design and operation of orepass systems. If such strategies were successful then the number of system failures would be difficult to explain. This section provides a template for a successful strategy in the planning, design and operation of orepass systems. 


\section{5. $1 \quad$ Tactical mistakes}

A review of several mining operations in Canada and South Africa has identified the following tactical errors that have resulted in multitude of problems in the operation of orepass systems (Table 4). It can be argued that these errors can and should be avoided.

Table 4 Tactical errors relating to the design and operation of orepass systems

\begin{tabular}{|c|c|c|}
\hline Type of Tactical Error & Example & Frequency \\
\hline Absence of clear objectives & $\begin{array}{l}\text { Absence of integrated approach to } \\
\text { account for operational, material and } \\
\text { stability elements concerns; isolated } \\
\text { design elements }\end{array}$ & $\begin{array}{l}\text { More common at feasibility } \\
\text { stage }\end{array}$ \\
\hline Inadequate data collection & Absence of pilot holes & $\begin{array}{l}\text { More common at feasibility } \\
\text { stage }\end{array}$ \\
\hline Lack of detailed engineering & $\begin{array}{l}\text { Focusing on stability and ignoring } \\
\text { material flow }\end{array}$ & Frequent at the design stage \\
\hline Control mechanisms & Absence of control chains & Frequent at the design stage \\
\hline Management & $\begin{array}{l}\text { Ownership and accountability of } \\
\text { orepass management }\end{array}$ & Common at the operation level \\
\hline
\end{tabular}

As shown in Table 4, these tactical errors have as much to do with human as well as operational resources. The only way for a strategy to succeed is for the company to establish both clear objectives and responsibilities that lead to an integrated approach engaging all the stakeholders at every part of the process.

\section{2 Strategy at the design stage}

Stacey (2004) has been a strong proponent of the design process as defined by Bieniawski (1992) and has illustrated that these design principles are readily adaptable to orepass design. This section provides a flexible strategy that can be implemented at any site.

\section{Design principle 1: Clarity of design objectives and functional requirements}

A statement of the "problem" and a statement of the design objectives, taking account of any constraints that are present, to satisfy this problem, is essential to any design process. In orepass design for example it is necessary to establish whether the mine aims to operate a single or a dual system, whether it will be operated with cushion guidelines (storage) or as flow-through, located near the shaft or the orebody, etc.

\section{Design principle 2: Minimum uncertainty of geological conditions}

The orepasses will be excavated in rock masses which can be very variable. In efforts to "control costs" it is not unusual to limit geotechnical investigations, with the result that geological conditions are often unknown or, at best, little known. A structural model will ensure that the orepasses are placed away from major geological structures. Drilling pilot holes in the preferred location for each segment of the system can allow the assessment of rock mass quality and provide data for the geotechnical assessment such as the $Q$ system by Barton et al. (1974) and the RMR system by Bieniawski (1989). Reliable classification records for the site can ensure that areas where the rock mass quality is poor $(Q<5, R M R<60)$ are avoided. The minimisation of uncertainty can result in more confident design in reduction of risk. An area that seems to be often overlooked is establishing the properties of transferred material in an orepass. Quite often there is scarce information on such critical properties such as particle size distribution, angle of repose, angle of friction, and mineral composition. 


\section{Design principle 3: Simplicity of design components}

An important step in the design of a rock pass is to develop a geotechnical model. This may be conceptual, but it is important to be able to describe the likely behaviour of the rock mass in which the pass is located and the possible mechanisms of instability. Only once this has been done can appropriate design (failure) criteria be decided on, design limits be defined, required factors of safety or probabilities of failure be defined, a design model (or models) be developed, and appropriate design analysis methods be decided upon. This will ensure that the design is appropriate, and as simple as possible.

\section{Design principle 4: State of the art practice}

The implication of this principle is that up to date concepts, analyses and methods must be used whenever they are appropriate. There are several developments in the engineering toolbox that can be used. These include sophisticated 3D stress analysis modelling (Figure 9).

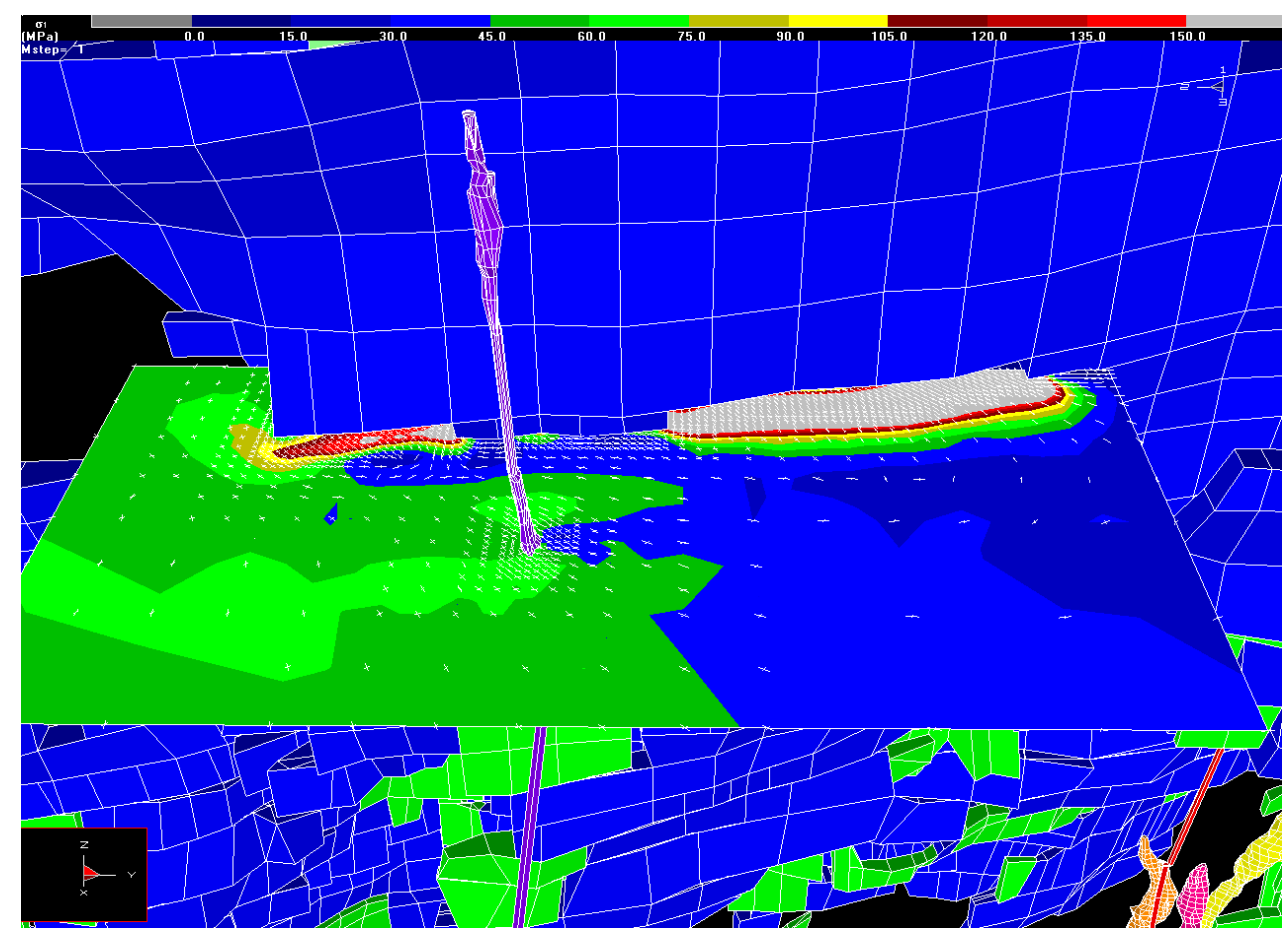

Figure 9 Map3D stress analysis of induced stress conditions around the 1000 SFR orepass, at Brunswick Mine, after Hadjigeorgiou et al. (2008)

Further tools include a range of design guidelines, see for examples Fergusson (1991), Stacey and Swart (1997), Beuss et al. (2001), Mercier-Langevin and Hadjigeorgiou (2004). Furthermore, Brummer (1998) as well as Hadjigeorgiou and Mercier-Langevin (2008) proposed quantitative methodologies that can be used to establish the projected longevity of orepass systems, based on ground and stress conditions, impact loads on the walls of the orepass, installation of suitable support and the implementation of proper orepass management techniques.

\section{Design principle 5: Optimisation}

Risk integrally involves numerous factors including safety, cost, productivity, seismicity, water, manpower, etc. Therefore, to minimise risk, designs must be optimised. An optimised design will result from the evaluation of the output from alternative designs. This would involve a trade-off study of the available design choices for orepasses. 


\section{Design principle 6: Constructability}

If the design cannot be implemented safely and efficiently it does not satisfy the principle of constructability and therefore is not optimised.

\section{Conclusions}

The argument that most mines do not have a strategy for planning design and operating orepass systems appears to be somewhat extreme. The fact that there are so many orepass problems would argue that this is in fact true, or at best the developed strategies are not successful. This raises the question why this is so.

A plausible explanation is that the financial costs of failed strategies have not been recognised. In the absence of documentation on hang-up frequency and production costs the information is not readily available to the decision makers.

Although most mines can quantify very well the construction costs and the "normal" operational (chute and rock breaker operation) and maintenance (chute and grizzly) costs, they do not have comprehensive data on what one may refer to as "irregular" costs such as hang-up clearing, rehabilitation, repairing blast damage to chutes, etc. It is these "irregular" cost that result in production losses, which is the single most important economic factor to consider.

An extreme example of the significance of orepass systems is provided in Figure 10 from an underground gold mine. In this case, the expansion of the orepass resulted in extensive production losses. This case is of particular interest in that the orepass was at a non-favourable orientation to the prevalent geological structure thus aggravating the situation. Another example that demonstrates the costs of lack of strategy is from a nickel mine where the mine had no alternative but to rehabilitate a critical orepass using a liner. The actual costs of the rehabilitation orepass were close to $\$ 7,000,000$ CAD.

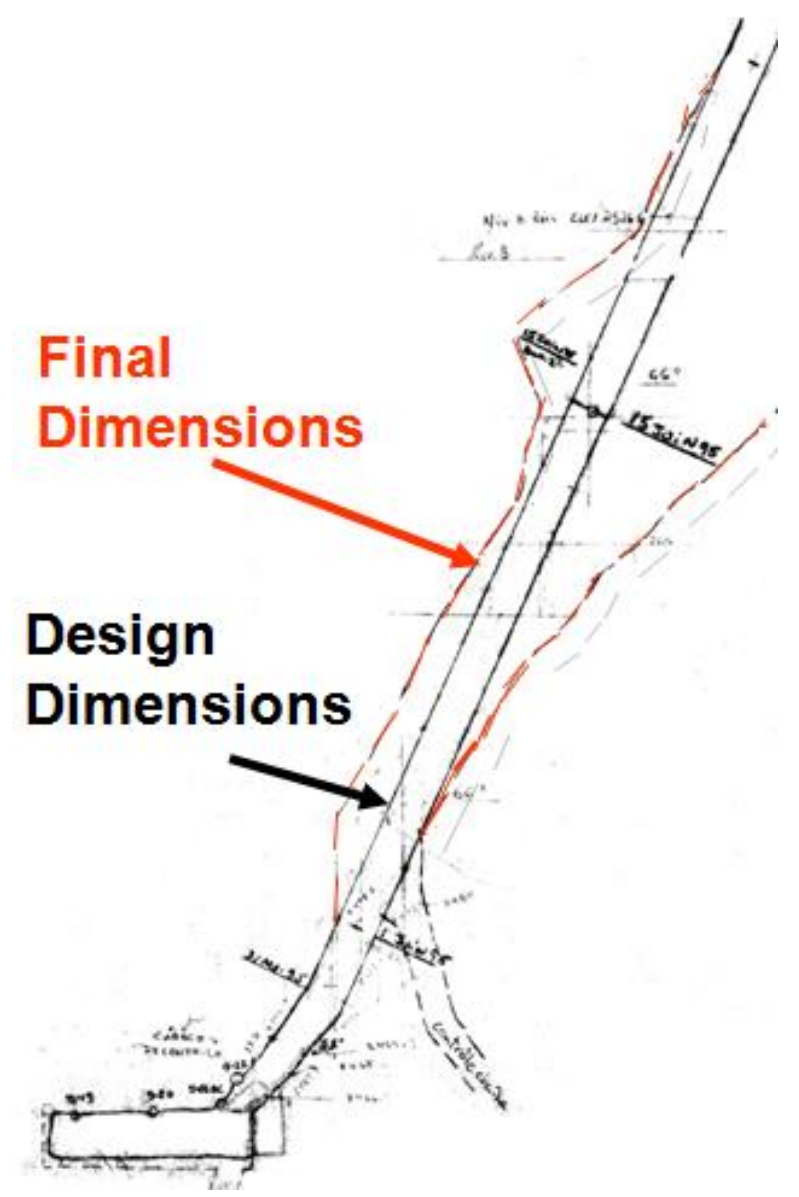

Figure 10 Failed orepass in that the expansion in the orepass resulted in severe production losses 


\section{Acknow l edgements}

The contribution of several colleagues at mine sites in North America and South Africa is greatly acknowledged. The opinions expressed in this paper are of the authors and do not necessarily reflect the opinion of various companies or institutions we have worked with in the past nor of our sponsors such as the Deepmine Research Programme, CRDD Institut de Recherche Robert Sauvé en Santé et en Sécurité du Travail (IRSST) and the Natural Science and Engineering Research Council of Canada.

\section{References}

Barton, N., Lien, R. and Lunde, J. (1974) Engineering classification of rock masses for the design of tunnel support, Rock Mechanics, Vol. 6, pp. 189-236.

Beuss, M.J., Pariseau, W.G., Steward, B.M. and Iverson, S.R. (2001) Design of Orepasses, In Underground Mining Methods, W.A. Hustrulid and R.L. Bullock (eds), Society of Mining Engineers, New York, pp. 627-634.

Bieniawski, Z.T. (1989) Engineering rock mass classification, Wiley, New York.

Bieniawski, Z.T. (1992) Design Methodology in Rock Engineering: Theory, Education \& Practice, A.A. Balkema, Rotterdam.

Brummer, R.K. (1998) Design of Orepasses: Methods for Determining the Useful Life of Ore-passes Based on Previous Experience and Case Studies, Report to CAMIRO Mining Division.

Butcher, R., Stacey, T.R. and Joughin, W.C. (2005) Mud rushes and methods of combating them, The Journal of The South African Institute of Mining and Metallurgy, Vol. 105, pp. 817-824.

Fergusson, G. (1991) Orepass Design Guidelines, Report for the Mining Research Directorate.

Goulet, C. (2000) Fonçage, Réhabilitation et Monitoring des Cheminées au Projet Bell-Allard, 14e Colloque en Contrôle de Terrain, Association Minière du Québec, Val d’Or.

Hadjigeorgiou, J. and Lessard, J.F. (2010) Strategies for restoring material flow in ore and waste pass systems, International Journal of Mining, Reclamation and Environment, Vol. 24, Issue 3, pp. 267-282.

Hadjigeorgiou, J. and Mercier-Langevin, F. (2008) Estimating Orepass Longevity in Hard Rock Mines, 42nd US Rock Mechanics Symposium, San Francisco.

Hadjigeorgiou, J., Esmaieli, K. and Harrisson, R. (2008) Observation of orepass system performance at Brunswick mine, Paper 13, CIM Bulletin, Vol. 101, No. 1110.

Hadjigeorgiou, J., Lessard, J.F. and Mercier-Langevin, F. (2005) Orepass practice in Canadian mines, The Journal of the South African Institute of Mining and Metallurgy, Vol. 105, pp. 809-816.

Joughin, W.C. and Stacey, T.R. (2005a) Risks Associated with Rockpasses in Deep Level Tabular Mines based on historical pass performance, The Journal of South African Institute of Mining and Metallurgy, Vol. 105, pp. 795-802.

Joughin, W.C. and Stacey, T.R. (2005b) The behaviour of orepasses in deep tabular mines, Second International Seminar on Deep and High Stress Mining, Sandton, South Africa, The South African Institute of Mining and Metallurgy, SS S37.

Lessard, J.F. and Hadjigeorgiou, J. (2006) Orepass Database: Quebec Underground Metal Mines, Canadian Institute of Mining Bulletin, March/April 2006.

Mercier-Langevin, F. and Hadjigeorgiou, J. (2004) Design Considerations For Orepass Systems In Massive Sulphide Nickel Operations, Report submitted to Mines Technology Department INCO Limited, p. 63.

Stacey, T.R. (2004) General Guidelines for the design of rock passes, The South African Institute of Mining and Metallurgy, Colloquium: Design, development and operation of rockpasses, Saxonwold.

Stacey, T.R. and Swart, A.H. (1997) Investigation into Drawpoints, Tips Orepasses and Chutes Vol. 1, Report to the Safety in Mines Research Advisory Committee, Project OTH 303. 